\title{
VERGÍLIO FERREIRA E JOSÉ SARAMAGO: ENSAIO SOBRE O HUMANO
}

\author{
Isabel Cristina Rodrigues*
}

À Luci Ruas

Com o homem começa o invisível

Rui Costa, Mike Tyson paRA PRINCIPIANTES

\author{
Saberemos cada vez menos o que é um ser \\ humano \\ José Saramago, epígrafe de $A s$ \\ INTERMITÊNCIAS DA MORTE
}

\section{Vergílio Ferreira e José Saramago, do impossível concílio?}

Conciliar na mesma frase o nome de Vergílio Ferreira e José Saramago náo deixa de ter os seus perigos, sobretudo porque, à tensa relaçáo pessoal efetivamente existente entre os dois escritores, os estudiosos de ambos se empenharam em fazer corresponder-lhe uma inequívoca dissidência no âmbito das respetivas obras, apoiada na aparente evidência de uma conformaçáo estilística e filosófica sumamente discrepante. De uma certa maneira não se enganam, embora esta certeza (talvez como qualquer outra) não possa continuar a sê-lo se não abrir a possibilidade da sua própria descrença, da sua própria implosão. Não procurando esconjurar o risco inerente a quem caminha sobre o arame, tratarei, portanto, de emular, ao longo deste exercício meramente congeminativo, o consabido expediente ficcional de Saramago que sempre permitiu ao escritor dinamitar o conforto das verdades instituídas: e se Ricardo Reis regressar do Brasil? E se os cruzados não tiverem ajudado os portugueses nas andanças do cerco medieval a Lisboa? E se o mal branco dos cegos se vier propagar ao comportamento eleitoral dos cidadáos? E se a morte deixar um dia de matar? E se as obras de Vergílio Ferreira e de José Saramago nos expuserem afinal idênticos problemas resolvidos por via de respostas distintas, ou mesmo idênticos problemas consubstanciados em possibilidades de resolução igualmente afins, ainda que sustentadas por uma rede argumentativa de natureza distinta?

\footnotetext{
* Doutora em Letras e professora da Universidade de Aveiro / CLLC (Portugal).
} 
Todos conhecemos as palavras que ambos deixaram escritas sobre o outro, com a verdade e a inverdade que a cada julgamento sempre corresponde e que remontam, no caso de Vergílio Ferreira, ao que o autor escreveu sobre José Saramago a propósito de O Evangelho Segundo Jesus Cristo no último volume da nova série de Conta-Corrente:

\begin{abstract}
O Vasco emprestou-me O Diabo em que mais vítimas do Saramago no Notícias aquando do PREC vêm apresentar a sua queixa pública. Mas do outro lado da barricada, onde se insulta o Lara e se defende o Saramago, ninguém se dá por achado. Acontece, aliás, que o Saramago disse há muito tempo que sim senhor fez muito bem em "sanear" esses sujeitórios e que voltaria a fazer o mesmo. // Posto o que, seria talvez útil para a compreensão dos botocudos explicar se possível sem silogismo porque é que era perfeitamente justo que o Partido Comunista pusesse na rua funcionários do jornal que tinham filhos a pedir a papa, e é altamente injurioso que o sujeito Lara lhe tenha riscado o nome para um possível prémio literário. (...) Para cúmulo, (...) o Independente da próxima sexta vai contar a história de um escritor brasileiro que se queixa que o Saramago the pilhou o Evangelho. E como isso vem do Brasil, a telenovela, especialidade do dito, vai aquecer com mais este episódio. Ontem escrevi ao Eduardo Lourenço e anotei o que para aqui vai. E dizia-lhe o que ninguém disse ainda e é que este Evangelho continua em melhoria $A$ Velhice do Padre Eterno. Há mesmo episódios convergentes. Assim, enquanto o Junqueiro aconselha o Cristo a ir às putas, o Saramago leva-o lá. Sempre é um avanço. Mas tudo isto passa um pouco ao lado do Evangelho, que não considero de modo algum um livro medíocre. Nem mesmo absolutamente enfadonho como tem sido acoimado. (Ferreira, 1994: 100-101) ${ }^{1}$
\end{abstract}

A par da ironia ácida com que Vergílio se refere a Saramago e da explícita dissensão ideológica que, no presente em que estas linhas foram escritas, de facto existia entre ambos, é notório o apreço do autor de Em Nome da Terra pelo Evangelho de Saramago (embora este apreço se exprima pelo avesso disfórico da linguagem - não considero medíocre; nem mesmo enfadonho), o que é tanto mais revelador quanto é sabido dos leitores e estudiosos de Vergílio que os entusiasmos do escritor por textos suamente alheios sempre recaíram em obras capazes de lhe devolver os traços ficcionais do próprio rosto - refiro-me, por exemplo, a Raul Brandáo ou Maria Gabriela Llansol. Estas palavras de Vergílio mereceram, no entanto, o seguinte comentário de Saramago, incomodado com a escassa deontologia do autor de Aparição - logo ele que, na página imediatamente a seguir, se dedicaria a roer a canela literária de António Lobo Antunes a propósito da fatídica sombra do Nobel que, em meados dos anos noventa, rondava a cabeça coroável dos três: ${ }^{2}$

\footnotetext{
${ }^{1}$ Cf. Ibidem, 181-182: "Os jornais trazem hoje a notícia dorida de que o Saramago, assim que tenha nas Canárias a sua casa pronta, passa-se para lá. Nós já tínhamos o modelo triste destes exílios: o Teixeira-Gomes no norte de África e o Castilho nas Ilhas. Mas aí houve ressentimento. Mas o Saramago de que poderá estar ressentido? (...) É um exílio, é um largar de mão o país. Um dia ele disse que o cristianismo foi uma utopia como o seu comunismo. Irá ele, com o país, largar também a utopia que foi nele? Não deve ser. Mas pode ser que o afastamento do país o alivie do peso da sua utopia, que está realmente cada vez mais pesada pelo próprio esvaziamento dela".

2 "Diz-se em Lisboa que o Nobel está no papo de Lobo Antunes. Pelos vistos, o jornalista brasileiro, conhecido de Jorge Amado, sabia do que falava. Também me dizem que Lobo Antunes já se encontra na Suécia". (Saramago, 1995: 212)
} 
Nunca dei por que os médicos, de modo geral e público, usassem fazer comentários desfavoráveis a respeito de outros médicos: provavelmente, depois de uns quantos milénios de prática do segredo profissional, já trazem a deontologia na massa do sangue. (...) Mas os escritores, ah, os escritores, com que gozo apontam eles ao desfrute do gentio a simples palha que lastima o olho do colega, com que descaro fingem não ver nem perceber a trave que têm atravessada no próprio olho. Vergílio Ferreira, por exemplo, é um mestre nesse tipo de execuçôes sumárias. Que se saiba, ninguém lhas pediu, mas ele continua a emitir sentenças de exclusão perpétua, sem outro código penal que o seu próprio e incomensurável orgulho sempre arranhado. Dizem que se decidiu finalmente a falar de mim na Conta-Corrente, mas não fui lá a correr ler, nem sequer devagar tenciono ir. A diferença entre nós é conhecida: eu não saberia escrever os seus livros, ele não quereria escrever os meus. (Saramago, 1995: 211)

O mais interessante deste testemunho de Saramago sobre o seu inimigo íntimo de filiação existencialista é precisamente a assunção da diferença que os une: Saramago não saberia escrever os livros de Vergílio, este não quereria escrever os de José Saramago. Ora, quereria Saramago escrever os livros de Vergílio, se de facto soubesse fazê-lo? Saberia Vergílio escrever os de Saramago, mesmo que nessa tarefa investisse a força da vontade? São questốes irrespondíveis estas, não só porque querer não é necessariamente saber (sendo que qualquer saber corresponde a uma verdade individual que recolhe da experiência intransmissível do sujeito muito do seu investimento mundividencial), mas ainda porque, no aparente dissídio das suas obras, os dois autores acabam por encontrar-se de um modo mais profundo do que por ação de um eventual (e deveras excêntrico) travestimento da respetiva identidade literária. Como quer que seja, a hipotética escassa vontade de Vergílio para assinar os livros de Saramago estaria com certeza associada aos escrúpulos ideológicos do escritor beirão, um férreo delator da retórica comunista nos anos posteriores à Revoluçáo de Abril de 1974. No sentido inverso da questão (na improvável situaçáo de que Saramago pudesse ter sido acometido de uma súbita vontade de intercâmbio autoral), facilmente se compreende que o lirismo contemplativo de Vergílio Ferreira, bem como o seu domínio tendencialmente extático da linguagem acabariam fatalmente por converter-se numa espécie de handicap técnico-estilístico para José Saramago, um escritor igualmente marcado pela intensidade do seu lirismo, mas que (como adiante haveremos de ver), busca outro cháo onde situar o corpo alado do seu programa lírico.

Sobejamente conhecido pela composiçáo de romances-ensaio (ou de romances-problema, designação esta que o autor prefere à primeira), a Vergílio Ferreira ficam ainda a dever-se alguns dos mais penetrantes ensaios sobre a cultura e a filosofia europeias e também sobre o seu prolongamento no domínio mais específico do literário, com particular destaque para os muitos textos que integram os cinco volumes de Espaço do Invisivel (publicados entre 1965 e 1998), sem esquecer, evidentemente, o título que ocupa a posiçáo cimeira no conjunto das suas obras ensaísticas - Invocação ao Meu Corpo, de 1969. Ao contrário de Vergílio, Saramago não se dedicou propriamente à escrita reflexiva do ensaio, nem assumiu como espaço mental de criaçẫo essa lógica de salto mortal que é de facto a do raciocínio especulativo, mas, tal como também sucedeu com o autor de Manhã Submersa, soube sempre integrar nos seus vários projetos 
ficcionais um ou outro eco da densidade reflexiva e da errância epistemológica características do ensaio, quer enquanto género, quer enquanto atitude. Assim se explicam, por exemplo, as palavras de Fernando Gómez Aguilera, que defendem para o autor de Manual de Pintura e Caligrafia o estatuto de um "ensaísta que a recorre a relatos e personagens para transmitir as suas crenças incómodas e combater as crenças irracionais" (Gómez Aguilera, 2013: 58). Embora a tonalidade ensaística da ficção saramaguiana se exprima por caminhos não exatamente coincidentes com os do romance-ensaio vergiliano (sobretudo na primeira fase da obra de Saramago, a proclamada fase da estátua), é bem notório o peso do exercício especulativo inerente à discursivização da escrita ensaística, náo só no corpo concreto da textualidade romanesca do autor, mas ainda na inscrição titular da mesma: Ensaio sobre a cegueira (1995) e Ensaio sobre a Lucidez (2004). Na realidade, ainda que de modo razoavelmente diferente, ambos os autores parecem ter compreendido a lição que Camus inscreveu no primeiro volume dos seus Carnets: "Si tu veux être philosophe, écris des romans" (Camus, 1962: 23).

Ainda que possa parecer estranho voltar a convocar Lobo Antunes para gerir os modos de aproximação dissonante de Vergílio Ferreira a Saramago, talvez a ousadia da convocatória se justifique pela justeza das afirmaçóes de Helder Macedo, não só sobre o autor de Manual dos Inquisidores, mas ainda a propósito do romance saramaguiano: "Lobo Antunes é um escritor de mundos interiores, mesmo quando exteriorizados em narrativas factuais" (Macedo, 2017: 298); "Mesmo quando escreve romances históricos objectivamente construídos até ao mais pormenor, Saramago escreve fábulas. Nunca fala de si, fala a partir de si" (Macedo, 2017: 298-299). Com efeito, é certo que António Lobo Antunes é um autor de mundos interiores, servidos por vezes, na sua eficaz eloquência compositiva, por estratégicas necessidades de exteriorizaçáo factual, de alcance maioritariamente histórico-mítico, como aquelas que na sua obra frequentemente remetem para os desaires da Guerra Colonial. Tal como Vergílio Ferreira, Lobo Antunes é um escritor do Homem mais do que da História (ou da História sempre que o Homem dela necessita para se definir como tal), embora as obras de ambos não sejam, evidentemente, sobreponíveis, tal como não podem sobrepor-se em exercícios de homologia completa as obras de Saramago e as do autor de Para Sempre, a nâo ser por via de um processo razoavelmente artificial de decantação literária.

$\mathrm{Na}$ verdade, a obra de José Saramago, pelo menos até ao romance $O$ Evangelho Segundo Jesus Cristo (1991), viveu muito da exterioridade factual da História e das histórias de que os livros se compunham, exterioridade essa servida por narradores tendencialmente omniscientes e recuados do fluir sinuoso das respetivas narrativas num gesto emocionalmente distanciador (embora ideologicamente cúmplice) em relação às agruras vividas pelas personagens. Opostamente, a obsessiva interioridade autodiegética dos romances vergilianos favorecia e potenciava a eclosão do exercício de questionação metafísica tão característico das suas personagens, exercício esse que era, nas narrativas de Saramago, programaticamente esconjurado pelo referido distanciamento emotivo entre o narrador e a matéria de que se compunha a sua narração e que o recorrente apelo do autor ao expediente retórico da fábula e da alegoria não fazia senão acentuar. 
No entanto, a curva no caminho que a obra de Saramago conheceu a seguir à publicaçáo de $O$ Evangelho Segundo Jesus Cristo e que, no dizer de Luciana Stegagno Picchio, sinaliza a existência (ocasionalmente simultânea) de "duas etapas sucessivas e sequenciais de uma única investigação expressiva” (Picchio, 2013: 14), vem abrir uma espécie de fratura existencial caucionada pela assunção de um novo tempo (o tempo da pedra) e que justamente vem legitimar o projeto involuntário da sua aproximação a Vergílio Ferreira e ao seu romance, porquanto o tempo da pedra parece ocupar-se menos da confiada horizontalidade da ideologia do que da vertical submersão da personagem no labirinto da espiritualidade humana. Romances como Todos os Nomes (1997), O Homem Duplicado (2002) e As Intermitências da Morte (2005), publicados todos eles quando Vergílio já não vivia, são romances que, por outro lado, o autor de Estrela Polar poderia ter escrito, que talvez até gostasse de ter escrito (embora necessariamente sustentados por uma outra atitude de linguagem), de onde se conclui que os dois romancistas se encontram de um modo muito mais profundo no ciclo da pedra (em que a distância ideológica entre ambos era já significativamente maior) do que no ciclo da estátua que Saramago localiza (e bem) na primeira parte da sua obra.

Assim se explica o autor no pequeno livro de autoanálise literária intitulado $A$ estátua e a pedra (2013) e que recolhe, entre outros textos de autorias diversas, a transcrição de uma conferência do próprio Saramago na Universidade de Turim:

Com este livro terminou a estátua. A partir de $O$ Evangelho Segundo Jesus Cristo (...) houve uma mudança importante no meu ofício de escrever. Não falo de qualidade, falo de perspectiva. É como se desde o Manual de Pintura e Caligrafia até a O Evangelho Segundo Jesus Cristo (...) me tivesse dedicado a descrever uma estátua. (...) Descrever a estátua, o rosto, o gesto, as roupagens, a figura é descrever o exterior da pedra. Quando terminei o Evangelho, ainda não sabia que tinha andado a descrever estátuas" (Saramago, 2013: 33-34).

A estátua de Saramago é uma estátua de palavras cosidas umas às outras com fervor, uma construção pensada para a eternidade da solidez ideológica do seu autor, em cujo tronco severo e claro a força da ideologia procurava requebrar a face mais ou menos oculta do pessimismo existencial do seu artífice. O rosto inexpugnável deste pessimismo haveria de se dar a conhecer mais tarde, sem a presença demasiadamente visível da sombra niveladora da ideologia procurando diluir o lugar da falha. O romance Ensaio sobre a Cegueira (1995) inicia, assim, a fase da escavação, a fase de deixar falar, como sucederá de facto no romance As Intermitências da Morte (Cf. Saramago, 2005: 77), o espírito inapreensível que paira sobre a água dos aquários e é também o nosso, inevitavelmente humano:

Tive de entender o novo mundo que se me apresentava ao abandonar a superfície da pedra e passar para o seu interior, e isso aconteceu com o Ensaio sobre a Cegueira. (...) O livro já não se empenha na descrição da estátua, é uma tentativa de entrar no interior da pedra, no mais profundo de nós mesmos, é uma tentativa de nos perguntarmos o quê e quem somos" (Ibidem: 34). 
Ainda que José Saramago continue sempre a escrever a partir da sua posiçáo de cidadáo, é já a mão do Homem que redireciona a prospeção do escultor para o interior da pedra, trazendo à superfície o avesso invisível das estátuas, o magma oculto de que parece nutrir-se a raiz do humano (cf. Ibidem, 37). Como a máo de Vergílio, a máo tardia de Saramago é a mão que sabe que "há uma aranha dentro de nós à procura de uma teia" (Ferreira, 1991: 141), tal como se diz no romance vergiliano Alegria Breve. Esta nova mão, antiga de sempre ter existido na dura latência da estátua, é uma mão fincada na humilde mineralidade do humano e é a mão que escreve os romances $O$ Homem Duplicado e As Intermitências da Morte, mas sobretudo Todos os Nomes, o mais vergiliano dos romances de Saramago e um dos seus textos mais belos, onde o próprio autor reconhece exprimir-se a "necessidade urgente de buscar o outro, talvez porque nessa busca um acabe por encontrar-se a si mesmo" (Saramago, 2013: 39). E o autor conclui:

\footnotetext{
Penso que neste romance há um caminho em direção ao essencial, e aqui regresso outra vez à metáfora da estátua e da pedra. É como se definitivamente tivesse abandonado o projeto de descrever a estátua (...) e penetrar mais profundamente na pedra escura do ser do que até entáo tinha sido capaz. (...) Em Todos os Nomes o universo passa a ser o espírito de uma pessoa que sente a necessidade de encontrar outra pessoa, e esse universo define-se na própria busca. (...) Esquecer é a morte definitiva e se lográssemos não esquecer (...) isso será prolongar a vida e os nomes das pessoas, dotá-las de uma outra existência” (Saramago, 2013: 39-40).
}

A mulher obsessivamente procurada pelo Sr. José, o discreto auxiliar de escrita da Conservatória do Registo Civil, não é nunca encontrada, ou só o é quando passa a habitar a morada final da morte, o lugar de todas as excedências. Porém, mesmo aí a mulher desconhecida continua a deslocar-se no labirinto do cemitério e da inquietaçáo do Sr. José, ocupando o lugar movente e ilocalizável da própria sepultura por ação de um metafísico pastor de ovelhas de guarda ao anónimo descanso dos suicidas:

a pessoa que está aqui, disse o pastor tocando com a ponta do cajado no montículo de terra, náo é a pessoa que você julga. De repente, o chão pôs-se a oscilar debaixo dos pés do Sr. José, a última pedra do tabuleiro, a sua derradeira certeza, a mulher desconhecida enfim encontrada, tinha acabado de desaparecer, Quer dizer que esse número está enganado, perguntou a tremer, Um número é um número, um número nunca engana (...) Nenhum dos corpos que estáo aqui enterrados corresponde aos nomes que se lêem nas placas de mármore, Não acredito, Digo-lho eu, E os números, Estáo todos trocados, Porquê, Porque alguém os muda antes de serem trazidas a colocadas as pedras com os nomes, Quem é essa pessoa, Eu" (Saramago, 1997: 239-240).

Deste modo, recluída já a personagem ao espaço de todos os silêncios, a mulher desconhecida do Sr. José, tal como a mulher de muitos dos romances vergilianos (Sandra, de Para Sempre; Mónica, de Em Nome da Terra; Oriana, de Até ao Fim; ou Bárbara, de Na Tua Face), configura um horizonte de busca plenamente irrealizável, ou que só não o é no plano da teimosa palavra do auxiliar de escrita, ao qual poderíamos perfeitamente atribuir algumas das afirmaçóes dos narradores de Vergílio, como o Paulo de Para 
Sempre: "Vou fazer-te existir na realidade da minha palavra. Da minha imaginação" (Ferreira, 1983: 60). Todavia, este modesto auxiliar de escrita vai ainda mais longe do que as personagens de Vergílio, rasurando, a conselho do próprio Conservador, a morte da mulher desconhecida por via da destruiçáo dos documentos que a atestam. Ela continuará oficialmente viva (e para sempre) na ilegalidade do seu registo forjado, à distância conveniente, portanto (até porque, em boa verdade, nunca chegamos a saber onde se encontram as pessoas que buscamos), da intenção imaginativa do Sr. José - "estás morta, posso inventar-te agora como quiser" (Ibidem: 60). Muito teriam a dizer um ao outro, se tivessem podido encontrar-se na vida imaginada que foi a de ambos, este funcionário da Conservatória do Registo Civil e o bibliotecário Paulo de Para Sempre:

\footnotetext{
Sabe o que eu faria se estivesse no seu lugar, perguntou, Não senhor, Sabe qual é a única conclusão lógica de tudo o que sucedeu até ao momento, Não senhor, Fazer para esta mulher um verbete novo, igual ao antigo, com todos os dados certos, mas sem a data do falecimento, E depois, Depois colocá-lo no ficheiro dos vivos, como se ela não tivesse morrido, (...) O Sr. José ficou entrou na Conservatória, foi à secretária do chefe, abriu a gaveta onde o esperavam a lanterna e o fio de Ariadne. Atou uma ponta do fio ao tornozelo e avançou para a escuridão. (Saramago, 1997: 278-279)
}

Quando pensamos em autores tâo intimamente dissonantes como Vergílio Ferreira e José Saramago, a tendência da voz crítica comum é promover a catalogação do primeiro como um escritor que obedece sobretudo a uma ordem imaginativa de caráter individual, psicológica e com explícitas tonalidades metafísicas (na linha dos mundos interiores de que fala Helder Macedo a propósito de Lobo Antunes) e a do segundo como uma voz efabulativa de alcance eminentemente coletivo e social e sustentada por premissas ideológicas solidamente assumidas. No entanto, à semelhança do que ocorre com o discurso oficial da História nos romances saramaguianos da fase da estátua, insistentemente questionados pelos narradores em face da sua ingente parcialidade, a meia verdade que acabei de enunciar é apenas isso: uma meia verdade, ou uma verdade parcial, até porque a rígida uniformidade dos catálogos se mostra fundamente inoperante se aplicada ao fazer literário dos grandes autores. Assim, nem Vergílio Ferreira foi imune à composição de romances "objetivamente construídos" (Macedo, 2017: 298), como o prova a sua instável e fugaz aproximação ao Neorrealismo (O Caminho Fica Longe (1943), Onde Tudo Foi Morrendo (1944) e Vagão "J”(1946)), nem José Saramago dispensou, pelo menos na fase tardia da sua obra, o apelo mineral da metafísica. $\mathrm{O}$ romance As Intermitências da Morte (2005), composto já no ciclo da pedra, é, por assim dizer, o livro-símbolo dessa curva desenhada no percurso literário de Saramago, ao integrar em simultâneo no seu corpo ficcional, por um lado, a memória implacável da estátua (a anonimização coletiva da morte, visível logo no início do romance, e a denúncia sócio-política dos negócios obscuros que em seu nome se realizam) e, por outro, a radiografia mineral da pedra, desdobrada em registos fotográficos cada vez mais profundos até atingir a densidade porosa do mineral onde se esconde a gadanha metafísica de um esqueleto à beira de se fazer mulher. 
Na ficção de Vergílio Ferreira, o ciclo da pedra (se bem que o exercício prospetivo que lhe corresponde não se tenha revelado completamente inoperante no período neorrealista do escritor) manifesta-se talvez a partir do significativo avanço mineral consubstanciado no romance Apariçāo, (1959) logo seguido de Cântico Final (1960), Estrela Polar (1962) e da volfrâmica desertificaçáo de Alegria Breve (1965). Na verdade, se o ciclo da estátua em Vergílio resulta, desde o seu início, na exposição de uma estátua grega, de certo modo carcomida já pelo peso dos séculos e pelo efeito das múltiplas intempéries que se foram abatendo sobre a casa do Homem, o romance Estrela Polar, determinando fortemente a pregnância simbólica e epistemológica da fase da pedra na obra de Vergílio Ferreira, possibilita a instituiçáo de uma homologia razoavelmente produtiva com o romance O Homem Duplicado (2002), o terceiro romance do ciclo da pedra na obra de Saramago, tal como Estrela Polar o é na obra vergiliana, depois de Aparição e Cântico Final. Estrela Polar e O Homem Duplicado são ambos, mau grado as suas expectáveis dissonâncias, romances onde a problematização da identidade é a verdadeira pedra de toque, apostando os respetivos autores na indagaçáo imaginativa da possibilidade da existência de "duplos absolutos" (Saramago, 2002: 30) a partir da gestação ficcional de "sósias, gémeos e duplicados" (Ibidem: 123): Aida e Alda, em Estrela Polar; Tertuliano Máximo Afonso e António Claro, em O Homem Duplicado:

Não se dispa, se não quiser, mas eu vou fazê-lo, não me custa nada, estou mais do que habituado, e, se a igualdade se repetir no corpo todo, você estará a ver-se a si mesmo quando me olhar a mim, disse António Claro. Despiu a camisa num só movimento, descalçou-se e tirou as calças, depois a roupa interior, finalmente as meias. Estava nu da cabeça aos pés e era, da cabeça aos pés, Tertuliano Máximo Afonso, professor de História. Então Tertuliano Máximo Afonso pensou que não podia ficar atrás, que tinha de aceitar o repto, levantou-se do sofá e começou também a despir-se, mais contido nos gestos por causa do pudor e da falta de hábito, mas, quando terminou, um pouco encolhida a figura devido ao acanhamento, tinha-se tomado em Daniel Santa-Clara, actor de cinema, com a única excepçáo visível dos pés, porque não chegara a descalçar as peúgas. (Saramago, 2002: 219)

Na realidade, tanto António Claro como Tertuliano, por um lado, e Aida e Alda, por outro, se punham a "inquietante questáo de saber quem é o duplicado de quem" (Ibidem, 176), embora os motivos que os levavam a querer sabê-lo não fossem inteiramente coincidentes. Em rigor, tanto Aida como Alda viviam bem com a sua igualdade perfeita, mas ao narrador Adalberto importava sobremaneira conhecer em qual das duas morava a face absoluta da mulher que o faria amá-la, só a ela e não à outra, a visão necessariamente gasta da primeira. ${ }^{3}$ Cientes os quatro de que, em cada par, "um de nós

\footnotetext{
${ }^{3}$ Por isso se questiona Adalberto do seguinte modo: "eram inteiramente iguais. E todavia, em quê diferentes? Porque aquilo que me unira a ela enquanto ela era Aida, que mistério absurdo o transformou em mim, o destruiu? Quando Alda foi Aida, que é que mudou nela para que já a não reconhecesse? (Ferreira, 2003: 47); "mas entáo, como te confundi? Tu única. Porque confundi Alda contigo nessa manhã de domingo na Mata? Há uma verdade de seres, irredutível, inconfundível: aceder a ela como? Em que impossível limite da minha sufocaçáo?" (Ibidem: 53).
} 
está a mais neste mundo" (Ibidem, 280), a pena para o crime metafísico da perturbadora identidade só poderia ser punível com a morte e assim o narrador mata Aida, depois de esta se ter feito passar pela irmá na vida de Adalberto, tal como o invisível destino mata António Claro ao volante de uma estrada repleta de enganos enquanto a sua mulher passa a noite com Tertuliano, julgando tratar-se do próprio marido. $\mathrm{Na}$ sequência do naufrágio em que perdeu a vida toda a sua família, Aida voltou do mar transformada em Alda, pronta a ocupar ao lado de Adalberto o lugar da irmá no afeto daquele (uma alma fundamente oprimida por torsóes metafísicas várias), promovendo assim o deslizamento da sua própria identidade, que o corpo não havia abandonado, para a identidade que habitava o corpo já morto da irmá. A personagem institui assim a possibilidade da criação de uma mulher toujours recommencée, como o mar no poema de Valéry lembrado por Vergílio e que encontra o seu equivalente simbólico no sonho das cem mulheres de Adalberto, ${ }^{4}$ mas também no explicit do romance de Saramago:

O enterro de António Claro foi daí a três dias. Helena e a mãe de Tertuliano Máximo Afonso tinham ido representar os seus papéis, uma a prantear um filho que não era seu, outra a fingir que o morto lhe era desconhecido. Ele havia ficado em casa, a ler o livro sobre as antigas civilizaçóes mesopotâmicas, capítulo dos arameus. O telefone tocou. Sem pensar que poderia ser algum dos seus novos pais ou irmãos, Tertuliano Máximo Afonso levantou o auscultador e disse, Estou. Do outro lado uma voz igual à sua exclamou, Até que enfim. Tertuliano Máximo Afonso estremeceu, nesta mesma cadeira deveria ter estado sentado António Claro na noite em que lhe telefonou. Agora a conversaçáo vai repetir-se, o tempo arrependeu-se e voltou para trás. (Ibidem: 317)

Como pode ver-se, com a mesma pedra se podem erguer estátuas distintas ou então, encarando a questão pelo seu avesso, talvez seja legítimo afirmar que algumas estátuas, mesmo exibindo traços nem sempre coincidentes, não têm por que erguer-se sobre pedras de distinta índole. No contexto particular da obra saramaguiana, é no tempo da pedra que o misticismo do seu autor se afirma não já contra Deus, mas ao lado de deus, quer dizer, em paralelo com tudo aquilo há de invisível na imaterial (e por isso também mineral) perceção do humano. Como lembra Eduardo Lourenço, num texto sugestivamente intitulado "Saramago: um teólogo no fio da navalha", o autor de As intermitências da Morte atreve-se finalmente a "descolar de toda a realidade humana para ver melhor ou de outra maneira a luz que ela oculta, a claridade original de cada ser humano ofuscada pelo peso do mundo que pode ser apenas o da nossa própria treva” (Lourenço, 1993: 187).

\footnotetext{
4 "Eram cem mulheres, contei-as, cem exactamente iguais, e eu só em face delas. Se uma erguia o braço, esse braço desdobrava-se paralelamente pelo friso das mulheres, sincrónico, exacto. Se havia um sorriso, e houve logo um sorriso, espalhava-se a alegria em cem sorrisos iguais. Mas como diante de cópias de uma fotografia, eu percorri-as de uma a uma, apesar de as saber repetidas. A certa altura, um gesto único lançou aos pés de todas os véus de tule. Havia agora uma uniformidade maior, porque eu olhava esses corpos nus, e o que distingue um corpo de outro é sobretudo a face que o sabe” (Ibidem, 52).
} 


\section{A morte, Deus e a sagraçáo do divino}

Embora o romance As Intermitências da Morte se inicie com a preocupaçáo de assinalar que "a morte sempre matou menos do que o Homem" (Saramago, 2005: 113), numa explícita referência, de inscrição ético-ideológica, à irracionalidade do gesto humano, a morte não deixa igualmente de ser nele descrita como um trauma individual, embora extensível à globalidade do Homem - uma sombra metafísica, portanto, até porque "a filosofia precisa tanto da morte como as religiōes, se filosofamos é por saber que morremos, monsieur le Montaigne já tinha dito que filosofar é aprender a morrer" (Ibidem, 40). Todavia, para além desta sua abordagem, digamos, tendencialmente metafísica e que ocupa a segunda parte do romance em causa, o autor propóe ainda uma análise da morte enquanto argumento legitimador do princípio da não divindade das religióes, preceito este que o autor já tinha elegido como objeto de frequentação ficcional em, por exemplo, Memorial do Convento (1982) ou O Evangelho Segundo Jesus Cristo (1991).

$\mathrm{Na}$ realidade, com a suspensáo generalizada da morte no seio da comunidade, os filósofos pessimistas, através dos quais procura exprimir-se o pensamento do próprio autor, vêm justamente lembrar o rombo que a sua falta introduz no corpo mercenário das religióes (essa espécie de agências funerárias das alturas), uma vez que, não havendo morte, também não há ressurreição e que, sem esta, as religiōes carecem de fundamento:

As religiōes, todas elas, por mais voltas que lhes dermos, não têm outra justificação para existir que não seja a morte, precisam dela como do pão para a boca. (...) Tem razão, senhor filósofo, é para isso mesmo que nós existimos, para que as pessoas levem toda a vida com o medo pendurado ao pescoço e, chegada a sua hora, acolham a morte como uma libertação, O Paraíso, Paraíso ou inferno ou coisa nenhuma, o que se passe depois da morte importa-nos muito menos do que geralmente se crê, a religião, senhor filósofo, é um assunto da terra, não tem nada que ver com o céu, Não foi o que nos habituaram a ouvir, Algo teríamos que dizer para tornar atractiva a mercadoria, Isso quer dizer que em realidade não acreditam na vida eterna, Fazemos de conta. (Ibidem, 38)

É muito curioso verificarmos que, sendo a suposta não divindade de Deus um ponto assente tanto para Saramago como para Vergílio Ferreira, há de facto uma clara dissensão entre ambos no tipo de argumentação aduzida para fazerem reconhecer a validade do seu posicionamento: se Vergílio Ferreira é um místico que vê na possibilidade de o Homem não ter existido a prova da não existência de Deus, Saramago é um místico zangado com o que Deus fez do Homem, o qual, pelo simples facto de existir tal como Deus o fez, insistentemente o nega e humilha, repelindo a apregoada bondade da criação como o fio do azeite à água que corre. Como afirma o escritor, "a existência do homem é a prova da inexistência de Deus" (Saramago, 1993: 26) e, por essa mesma razáo, a existir, Deus "é um imbecil, porque só um imbecil teria criado a espécie humana como ela é" (Ibidem, 72). Assim sendo, e embora Deus tenha sido um dia surpreendido pelo Zé Fernandes de Eça a sorrir enquanto folheava Voltaire numa edi- 
ção barata, o Deus de Memorial do Convento "não sorri, ele lá saberá porquê, talvez tenha acabado de se envergonhar do mundo que criou" (Saramago, 1982: 328).

Por seu turno, a suposta não divindade de Deus defendida por Vergílio Ferreira e, no contexto da sua ficção, também por algumas das suas personagens (a Guida de Cântico Final, o narrador Jorge de Nitido Nulo, Adalberto de Estrela Polar e, de certo modo, também a mãe de Cláudio, o narrador de Até ao Fim) resulta, em primeira instância, da necessidade primordial de existirem homens para que seja possível qualquer interrogação sobre Deus, até porque, na realidade, a questâo da existência de Deus só se póe porque há homens para a pôr. ${ }^{5}$ Parece-me, pois, que é nesta premissa da obrigatoriedade do humano (prévia a qualquer impulso de interrogação) que Vergílio Ferreira assenta a sua argumentação sobre a não existência de Deus, argumentação essa que, à margem da ficção onde também se faz sentir, o autor desenvolveu em inúmeros textos inseridos nos volumes de Conta-Corrente ou de Espaço do Invisivel:

Todo o mistério e enigma começa com a existência do homem. Mas e se o homem não existisse? Naturalmente dir-se-á que em tal caso não se podia pôr questáo nenhuma. Mas eu, que existo, posso pô-la agora para um tempo em que nunca pela eternidade do cosmos, viesse a haver homens. Estou cá apenas para formular a questấo do que poderia significar o problema de Deus no caso de não haver jamais seres humanos. E isto para tirar a conclusão de que se tal se verificasse, o problema de Deus não tinha sentido nenhum. (...) Um Deus para um mundo desabitado seria inconcebível como Deus na sua solidão absoluta e um acrescentamento ridículo de um cosmos de pedras. A ideia de Deus implica-se na ideia de uma necessidade da existência de homens. Mas o homem é acidental e não vamos deduzir a sua necessidade pelo facto casual de ter existido, porque a sua verdade está em não ter existido, exactamente porque só por um acaso (infinitesimal) ele existiu. Todas as nossas relaçôes com Deus têm de estabelecer-se assim em face de um mundo em bruto. (...) Se o homem nunca existisse, é ridículo, imbecil, absolutamente incompreensível que se pusesse a seu respeito o problema de Deus. Porque um Deus que criasse um mundo de pedras seria um Deus idiota. (Ferreira, 1993, 396-397) ${ }^{6}$

Com efeito, em todos os textos onde Vergílio Ferreira reflete sobre a inevitabilidade racional da não existência de Deus, é o argumento da acidentalidade do homem

${ }^{5}$ Cf. Invocação ao Meu Corpo: "o problema de Deus teve de esperar pelo homem para que pudesse ser posto. (...) Assim Deus teve de esperar pelo homem para que a sua existência fosse posta em causa, para que de facto existisse, se porventura existisse. Um Deus existindo apenas em si mesmo, precisaria ainda de alguém que o reconhecesse, lhe desse o estatuto de ser, como um homem isolado num deserto ou num mar. $\mathrm{O}$ absoluto de si, para que absoluto fosse, precisaria de um homem que o fixasse aí, o "limitasse" aí, para o definir, o determinar como tal” (Ferreira, 1969: 214).

${ }^{6}$ Cf. Espaço do Invisivel 5: "Que é que poderia significar Deus em face de um universo despovoado, sem a acidentalidade da existência humana num ápice brevíssimo da eternidade do universo? Porque seria então um Deus absurdo, sozinho no seu jogo infantil com as bolas de pedra perdidas no obtuso da eternidade de um mundo." Veja-se ainda o fragmento 48 de Pensar (p. 51): "Que é que significa um universo feito provavelmente de simples bolas de pedra e fogo? E que tudo se afunde um dia em matéria inerte? Que é que significa, nesta absurdidade sem fim, a ideia incrível ou abdicativa da existência de Deus? Estás daí a vê-lo a contemplar da varanda do infinito os seus dinossauros durante 200 mi...i...lho...ó...es de anos? Ou a jogar pelo sem-fim com as suas bolas de pedra?" (Ferreira, 1998: 51). 
que sustenta o desenvolvimento do seu pensamento questionador, sobretudo porque este argumento lhe permite pensar o absurdo que seria Deus sem um homem para o questionar. $\mathrm{O}$ absurdo de Deus, porém, mantém-se mesmo existindo o homem, porque ele podia perfeitamente náo ter existido e isso faria da divindade uma criatura inútil, fora da esfera do divino, portanto, e eternamente rodeada de pedras, como antes o teria estado apenas de dinossauros. Consequentemente, a relação do homem com Deus deve, para o escritor, equacionar-se náo no contexto de um mundo povoado pelo homem, mas no de um mundo só de pedras. Deus não pode, pois, ter criado o homem, uma vez que este último é um mero acidente na misteriosa história do cosmos e que por milhóes de anos o mundo existiu sem que ele o habitasse. Para Vergílio Ferreira, Deus não é, afinal de contas, mais do que um nome "com que se responde à interrogação sobre o homem e o universo" (Ferreira, 1987: 364) ${ }^{7}$ e nasceu "da nossa absoluta incapacidade de imaginar o nada. A tudo chega a nossa imaginação. Excepto ao lado de lá da morte. Foi aí que pusemos os deuses para nos ajudarem" (Ferreira, 1980: 350). O milagre da criação tende, assim, a inverter-se e da ideia de um Deus criador do homem chegamos à ideia de um homem que é, afinal, o criador do próprio Deus, o deus de Deus, portanto, como já o Zaratustra de Nietzsche tinha sublinhado ("Ah, Meus irmãos, esse Deus que eu criei era obra humana e delírio humano, tal como todos os deuses!" (Nietzsche, 1996 [1891]): 34) - "Mas Deus", escreve Vergílio Ferreira, "também não era nada antes / de eu conhecê-lo ou de inventá-lo em meus / sonhos de eternidade. Nos instantes / da vida inteira sou pois deus de Deus" (Ferreira, 1981: 80). ${ }^{8}$ Ora, algumas das personagens vergilianas vêm justamente sublinhar a não divindade de Deus e a realidade da sua matéria humana, tal como, num gesto autorreflexivo que lhe é táo caro, o próprio escritor confessa:

No meu Cântico Final Guida diz que os deuses não são divinos e que basta dizermos a palavra "Deus" para lhe sentirmos o absurdo. Em Aparição o narrador tem uns versos em que se diz que os deuses nascem do sangue e a ele tornam, porque só aí são eternos e que são assassinados pelas religiōes. E no Espaço do Invisivel I fala-se da voz excessiva do homem, da sua voz obscura, de um apelo ao máximo, do seu limite impossível, para se concluir que tudo isso é do próprio homem. (...) Fala-se nos três livros - e noutros - da mesma coisa e essa coisa é o limite que se corporiza na palavra "Deus". (Ferreira, 1987, $447)^{9}$

\footnotetext{
${ }^{7}$ Cf. Carta ao Futuro: "Deus náo é um ídolo sonhado a ouro e a incenso, diante do qual nos sintamos redimidos pela renúncia e esquecimento, mas é antes o espelho da interrogaçáo original que nos veio no sangue. (...) À medida que um deus existe, ele deixa de ser divino. Divino é só o alarme, a evidência do que somos, do sinal obscuro de tudo o que nos rodeia" (Ferreira, 1966: 52-53).

${ }^{8}$ Cf. Invocação ao Meu Corpo: "Erguemos o deus ao seu trono de luzes, mas, mal ajoelhamos, sabemos que fomos nós a erguê-lo" (Ferreira, 1969: 41).

${ }^{9}$ Nesta mesma página de Conta-Corrente 5, Vergílio Ferreira enuncia algumas das preocupaçóes partilhadas pela personagem Ema de Alegria Breve, justamente por entender, tal como a referida personagem (que defendia uma espécie de panteísmo sem nome - o inominável, como ela dizia), que Deus não pode ter nome, porquanto um nome limita o nomeado e Deus, a existir, terá que ser o ilimitado de toda a realidade, mesmo a da pala-
} 
Para lá de Cântico Final e Apariçăo $0^{10}$, vários outros romances insistem na ideia da humanidade de Deus, correlata, portanto, da impossibilidade de comunicação do homem com a (deste modo inexistente) transcendência divina. Quando, em Estrela Polar, Emílio exige que Adalberto dê um nome ao transcendente, ou a alguém que, como ele diz, unificasse todos os diálogos possíveis (Deus), Adalberto furta-se à verbalizaçáo desse termo pretendido pelo amigo, embora não por hesitação ou cobardia, mas porque provavelmente pressente na divindade de Deus a verdade maior da mão do homem, concluindo por isso que não é divina, mas antes profundamente humana, a palavra onde Emílio julga poder Adalberto encontrar a salvação:

- Pois, pois. Tu dizes: há uma zona em nós inacessível. Aí o homem está só. Nenhum diálogo o atinge. Para salvar isso, para que isso se justifique, tem de haver alguém acima desse diálogo. Mas chegado aqui, tu paras. Tens o nome debaixo da língua para esse alguém. Um alguém que unifique todos os diálogos possíveis. Porque não és corajoso? Diz o nome e não há mais problemas. // Não acabará pois a obsessão do divino? (...) A palavra que nos queima a boca é uma palavra humana. As questóes dos homens resolvem-se entre homens. (Ferreira, 2003: 71-72)

Por essa mesma razáo vem defender o padre Bartolomeu Lourenço, em Memorial do Convento de Saramago, a dispensabilidade da bênçáo eclesiástica pedida por Blimunda: "Deite-nos a sua bênção, padre, Não posso, não sei em nome de que Deus a deitaria, abençoem-se antes um ao outro, é quanto basta, pudessem ser todas as bênçãos como essa" (Saramago, 1982: 194). Foi esta também, aliás, a liçẫo aprendida pelo narrador João de Em Nome da Terra, ao batizar a cabeça de Mónica com a água livre do rio, devotos ambos que o eram da religiáo profana do amor:

Por fim saímos da água e os deuses olharam-nos, humilhados na sua inutilidade. (...) Trazíamos a notícia de um corpo incorruptível e perfeito.

- Jura-me que nunca hás-de envelhecer - disse-te.

- Juro.

- E que nunca hás-de morrer.

- Sim.

- E que a beleza estará sempre contigo. E a glória. E a paz.

- Juro.

Então baixei-me ao rio e trouxe água nas mãos em concha. E derramei-ta na cabeça. E disse, e disse

vra - "Deus não é um boneco, Deus não tem nome, Deus é o que ê" (Ferreira, 1991: 155). Por isso escreve o autor que a palavra Deus "torna-o já limitado, perceptível e de algum modo conceptuável. Deus é realmente o limitado do ilimitado de nós, a resposta a uma interrogaçáo que a não tem, a positivaçáo do impossível de nós. Deus é a nossa criação no incompreensível de nós e do mundo, o indefinível da nossa indefiniçãa, o repouso do que existe apenas como inquietação. (...) Mas dizê-lo real ou dizê-lo simplesmente é despromovê-lo, baixá-lo em relação ao indizível da nossa inquietação e do nosso impossível. Deus só é não sendo, porque só aí mantém o ilimitado da nossa procura, só aí mantém afinal a sua divindade" (Ferreira, 1987: 447).

${ }^{10} \mathrm{Cf}$. Aparição: "Do sangue nascem os deuses / que as religiôes assassinam. / Ao sangue os deuses regressam / e só aí são eternos” (Ferreira, 1959: 38). 
- Eu te baptizo em nome da Terra, dos astros e da perfeiçáo.

E tu disseste João sacrílego. E eu disse agora podemo-nos vestir. (Ferreira, 1990: 16)

Em suma, coincidindo tanto Vergílio Ferreira como José Saramago no entendimento da religiáo apenas como um produto do apelo humano, é de facto com o Homem que começa o invisível como reduto da espiritualidade, tomando este invisível o nome de deus ou de outra coisa ainda - e, para estes dois autores, essa coisa é que é linda, quer se trate do amor, da arte, ou da razáo inexpugnável da moral, todas elas visóes alternativas ao Deus das alturas que a si próprio sempre se negou. Todavia, embora exista em Vergílio e em Saramago uma desmedida propensão indagadora, creio que, para este último, a ideia de um deus que o fosse apenas em terreno humano, uma espécie de deus de laboratório ou concebido em registo de distanciamento alegórico (plasmado, por exemplo, na observância social da ética ou na comunhão amorosa), cumpriria bem a sua funçáo de deus para a necessidade horizontal do Homem; ao invés, para um romancista e um ensaísta com a vocação nostálgica de Vergílio Ferreira, a intranscendência de um deus concebido apenas na esfera do Homem, por via da sintaxe do seu gesto demasiadamente terreno, seria ainda e sempre o signo da sua orfandade metafísica, a criação substitutiva, mas do lado de cá, de uma instância para sempre ausente do lado de lá.

Ora, neste contexto, a propósito do apregoado (mas não necessariamente rigoroso) ateísmo de Saramago, parecem cobrar particular sentido as palavras de Manuel Frias Martins, que vem defender, relativamente ao autor de Ensaio sobre a Cegueira e na linha do pensamento de um Leonardo Boff), a existência de uma espiritualidade clandestina vivida à margem do princípio da transcendência religiosa e em contínua busca de uma linguagem capaz de dizer ao Homem "o sentimento do mistério do mundo, da profundidade humana” (Boff, 2010):

é como se a invocação do ateísmo funcionasse como uma espécie de ocultação tática de um segredo autoral que alguns romances, lidos a partir de um impulso muito particular, estariam dispostos a identificar e a revelar em termos de espiritualidade clandestina. (...) a espiritualidade atravessa os romances ao ritmo dúvida e do desassossego de um autor em busca de sentido para o humano e sobretudo para as construçóes humanas do divino" (Martins, 2014: 19).

Em ambos os escritores (Vergílio e Saramago), há de facto uma urgência espiritual a que a religiáo não sabe (ou não pode) dar resposta e que só encontrará na visão intranscendente do sagrado a palavra certa do repouso, pelo que o "ateísmo ético" de Saramago (cf. Boff, 2010) e a nostálgica retórica da descrença em Vergílio só poderáo resolver-se no entendimento em experiência da moral, do mistério do amor, da beleza ou do sagrado da arte enquanto catacrese, quer dizer, enquanto um modo indefinido de empréstimo capaz de encontrar, para o sentido indagador do humano, o conforto ou a estabilidade conceptual de um nome a que o Homem possa acolher-se: 
Olho-te agora na memória legenda e a beleza impossível existe, que para isso é que é impossível. Às vezes, no silêncio, por entre o rumor da folhagem - espera. Eu dizia-te espera e ficávamos ambos a ouvir quando não se ouve nada - que é que ouvíamos? Vou pensar. Uma música, não, não. Voz das coisas, da terra. Suponhamos a voz de Deus que é a mais provável quando não há nenhuma, nem a dele. (Ferreira, 1990: 12)

É assim, em função do proselitismo de ambos, que Saramago e Vergílio Ferreira propóem, nas suas respetivas ficçóes, a humanização da figura de Cristo: se Deus não existe, Cristo está entre nós, ama como nós, sofre na alma de que também é feito as mesmas agruras dos humanos. Deste modo, se bem que a humanização da figura de Cristo alimente todo o universo ficcional de $O$ Evangelho sobre Jesus Cristo, a prova efetiva do entendimento crístico do Homem está, de um modo talvez mais eloquente, em Memorial do Convento, na figura humilde de Baltasar Sete-Sóis e na ausência de divindade do seu corpo aguardando a morte, como a do narrador Joáo de Em Nome da Terra, também ele nada mais do que um corpo à beira do fim, olhando em espelho a imagem sem cruz do sofrimento de Cristo: ${ }^{11}$

A queima já vai adiantada, os rostos mal se distinguem. Naquele extremo arde um homem a quem falta a mão esquerda. Talvez por ter a barba enegrecida, prodígio cosmético da fuligem, parece mais novo. E uma nuvem fechada está no centro do seu corpo. Então Blimunda disse, Vem. Desprendeu-se a vontade de Baltasar Sete-Sóis, mas não subiu para as estrelas, se à terra pertencia e a Blimunda. (Saramago, 1982: 373)

\section{O lirismo e o feminino}

O explicit de Memorial do Convento acabado de transcrever é de um lirismo intenso, tal como o são tantos outros fragmentos da ficção saramaguiana, embora não possamos referir--nos à intensidade lírica do romance de Saramago do mesmo modo que defendemos a viabilidade analítica do romance vergiliano como romance lírico, porquanto me parece que o lirismo na obra de José Saramago é um lirismo sobretudo de situação, mais do que do discurso em que a situação se dá a ver: é um lirismo evanescente, impalpável, rondando sempre o corpo explícito da palavra, mas como que subtraído ao impudor do discurso por um narrador que aposta maioritariamente nos efeitos de uma poeticidade de caráter efabulativo, que não necessita de contaminar liricamente o domínio da linguagem para se fazer dizer. É assim que as palavras nos

\footnotetext{
${ }^{11}$ Cf. Em Nome da Terra: «hoje falei com o Cristo que tenho aqui. (...) O reconhecimento de um homem por outro homem, não do lado triunfante mas da humilhação, não do da alegria mas do sofrimento, não do da saúde mas de um corpo apodrecido. (...) E é só aí que me interessas. Na lástima desse teu corpo. $\mathrm{Na}$ amargura da solidão. Como te devias sentir só. É só aí que te entendo para me entender a mim. Só na dor absoluta de um homem sem divindade nenhuma». (Ferreira, 1990: 69-71)
} 
dão a ver a beleza dos gestos de Baltasar e Blimunda, mas é para lá delas que essa beleza se dá a conhecer, porque a teia discursiva é como um vidro transparente sobre aquilo que a transcende e chega enfim até nós. Por outro lado, creio que, na ficçáo de Saramago, a visão lírica do humano está resguardada da face visível do discurso não apenas por uma questão de pudor da linguagem, mas também porque a exterioridade testemunhal do narrador inibe o seu acesso à intimidade verbal das personagens e ainda porque, num mundo em busca de solução para a deriva ético-moral do Homem, agir poeticamente (e por isso moralizando a sintaxe do gesto humano) é mais importante do que deixar falar o verbo lírico. Também por isso se constroem fábulas e alegorias na narrativa saramaguiana, já que estas funcionam como um expediente retórico de inibiçẫo de um pathos tendencialmente associado ao processo de discursivizaçâo lírica.

Necessitando o lirismo em José Saramago da exterioridade da açáo para se manifestar, o Sr. José de Todos os Nomes, para devolver à vida a mulher desconhecida, foi forçado a refazer o verbete que lhe correspondia na Conservatória do Registo Civil, rasurando no dito verbete a data da sua morte; Vergílio Ferreira nunca o faria, até porque não precisaria de fazê-lo: a presentificação do feminino na narrativa vergiliana não se efetiva no plano do agir, mas no plano de uma dicção passível de dissipar (ou mesmo de contrariar) a face visível das verdades mais incómodas. Por isso a imposição da palavra lírica, porque só ela resta por sobre todas as ausências. Deste modo, a retração comunicativa da mulher e do mundo imposta a um narrador autodiegético e em situação de recolhimento existencial (a prisão, a velhice, o lar de idosos) abre espaço à eclosáo do impudor irrefreável do verbo amante, porque este náo encontrará já como direção preambular do seu dizer o horizonte discursivo do outro.

No entanto, a divinização liricizante da mulher no romance de Vergílio Ferreira (sobretudo em Para Sempre e nos romances subsequentes) atua quase como um filtro que instabiliza a defesa da prevalência moral do feminino (que José Saramago, por sua vez, empreende programaticamente). A personagem feminina em Vergílio é normalmente objeto de um amor intenso em forma de discurso, a cujo excesso ela própria procura por vezes furtar-se, mas não é nunca o agente ativo de um qualquer ensinamento capaz de guiar o homem no seu trajeto dificultoso pelo mundo: "Jamais Sandra teve para mim um gesto, uma palavra, uma atitude mais aberta de intimidade. Dominada controlada frígida de correcção. Eu explodia de expansão emotiva, ela tratava-me com uma palavra breve correcta neutral" (Ferreira, 1983: 204).

A este propósito, no seu iluminante texto sobre a questão do feminino em José Saramago (Macedo, 2017: 185-194), Helder Macedo invoca justamente as obras de Alves Redol e Cardoso Pires para lembrar que as mulheres em modo de personagem, reagindo muitas vezes contra o propósito de dominação masculina, acabam ainda por traduzir "as percepçóes masculinas da condição feminina" (Ibidem, 186). Creio que Vergílio Ferreira também não teria feito má companhia a Cardoso Pires e Alves Redol. Neste sentido, a mulher desconhecida de Todos os Nomes é talvez a mais vergiliana de 
Saramago - deixa-se buscar e habita, ao contrário das outras, o lugar de todas as ausências: não fala, não alerta o homem para as coisas do mundo, apenas existiu na imobilidade do seu recuo para que um dia o Sr. José a procurasse.

Opostamente, na ficção de Saramago "a mulher é o agente activo do amor" (Ibidem, 185), até porque, como se afirma em Memorial do Convento, "Deus, quando quer, não precisa de homens, embora náo possa dispensar-se de mulheres" (Saramago, 1982: 17). Na verdade, é Blimunda, "a mulher de olhos excessivos" (Ibidem, 184), que procura Baltasar no final do romance; é a morte em figura de mulher que procura o violoncelista em As Intermitências da Morte e é Maria Sara que procura Raimundo Silva em História do Cerco de Lisboa. Já em Manual de Pintura e Caligrafia, como o próprio escritor reconhece, "a mulher aparece como um forte elemento de transformação, porque sem ela, sem o "outro" que ela é (...) o pintor H. não chegaria a descobrir que os caminhos pelos quais transitava náo o conduziriam ao conhecimento de si mesmo como homem e como artista" (Saramago, 2013: 21).

No romance As Intermitências da Morte (místico como talvez nenhum outro do autor, até porque, no dizer de José Augusto Mourão, "o termo místico não é um predicado, quer dizer, náo delimita uma classe de objetos, (...) é uma certa intensidade que pode percorrer qualquer outro domínio" (Apud Eiras, 2017: 139)), é como se a mulher desconhecida do Registo Civil fosse resgatada ao romance Todos os Nomes e aos ficheiros da morte para a humana experiência do amor junto de um homem que não é já o Sr. José, mas um violoncelista que aparece para vingar a infundada busca daquele. Aquilo que a peregrinação do escriturário do registo civil não conseguiu obter (a presença da mulher) conseguiu-o agora a música de Bach nos dedos de um violoncelista de meia idade que o narrador qualifica como um "sobrevivente de si mesmo" (Saramago, 2005: 158) - em primeiro lugar, porque pôde sobreviver à morte que the havia sido destinada por essa ordem obscura que a todos regula, mas ainda porque soube sobreviver ao fracasso da expedição do Sr. José, vingando o vazio da mulher desconhecida na cama deste último ao receber amorosamente a morte em figura de mulher, restituída esta à banalidade amorosa do mundo por ação de uma suite de Bach e de um fósforo humilde sobre um papel violeta de cuja combustáo náo restaram cinzas.

Como nas ficçóes de Vergílio Ferreira, onde o sagrado da música era por vezes a face mais visível da luz que o feminino expendia ("Mónica. Meu doce oboé" (Ferreira, 1990: 58)), o amor pôde vencer a morte em As Intermitências da Morte porque pôde contar com o poder redentor da música, explicado assim pelo narrador ao corpo renovadamente humano da morte: " $\mathrm{Tu}$, que te havias habituado a poder o que ninguém mais pode, vias-te ali impotente, de mãos e pés atados, com a tua licença para matar zero zero sete sem validez nesta casa, nunca, desde que és morte, reconhece-o, havias sido a esse ponto humilhada. Foi então que saíste do quarto para a sala de música, foi então que te ajoelhaste diante da suite número seis para violoncelo de johann sebastian bach" (Saramago, 2005: 162). Quanto não teria dado Vergílio Ferreira por fazer a 
morte ajoelhar-se diante de uma peça de Bach, ele que tantas vezes o fez de modo simbólico, mesmo sem ter obrigado a figura nefanda da gadanha a dobrar em vénia o corpo descarnado.

Deste modo, embora num sentido diferente ao de Aida e Alda (as gémeas verdadeiras de Estrela Polar) e de Tertuliano e António Claro (de O Homem Duplicado e que bem podiam tê-lo sido, gémeos verdadeiros), creio que Vergílio e Saramago é isso que de certo modo são: gémeos espirituais, mas falsos - não partilham o mesmo adn filosófico, político e até mesmo literário, embora na sua folha de rosto continue bem visível a identidade familiar dos traços.

Resumo: O presente texto pretende questionar a defesa do impossível concílio existente entre Vergílio Ferreira e de José Saramago (comummente verbalizada por leitores e estudiosos das suas respetivas obras), procurando expor o modo como ambos, apesar de evidenciarem uma conformação estilística e filosófica razoavelmente distinta, privilegiam a problematização ficcional de questôes afins.

Palavras-chave: romance-ensaio; figuração do feminino; inexistência de Deus

Abstract: This article aims to reexamine the grounds underlying the argument of the impossible reconciliation of Vergilio Ferreira and José Saramago (often voiced by readers and critics of their respective works), by seeking to show how both authors, notwithstanding their fairly distinct stylistic and philosophical leanings, give priority to the fictional enactment of similar questions.

Keywords: Essay novel; feminine images; non-existence of God

\section{REFERÊNCIAS}

BOFF, Leonardo (2010), "Espiritualidade à mesa, em Estocolmo”. In https://cultura.estadao.com. br/noticias/geral,espiritualidade-a-mesa-em-estocolmo-imp,569005

CAMUS, Albert. Carnets I. Paris: Gallimard, 1962.

EIRAS, Pedro. Ensaio sobre os Mestres. Lisboa: Documenta, 2017.

FERREIRA, Vergílio. Carta ao Futuro. 2 ed. Lisboa: Portugália Editora, 1966 [1958]. . Alegria Breve. 6 ed. Lisboa: Bertrand, 1991 [1965]. Aparição. 59 ed. Lisboa: Bertrand, 2001 [1959]. . Estrela Polar. 5 ed. Lisboa: Bertrand, 2003 [1962]. . Conta-Corrente 2. Lisboa: Bertrand, 1981. Para Sempre. Lisboa: Bertrand, 1983. Conta-Corrente 4. 2 ed. Lisboa: Bertrand, 1993 [1986]. Conta-Corrente 5. s.l.: Bertrand, 1987. Em Nome da Terra. 2 ed. Lisboa: Bertrand, 1990 [1990]. Conta-Corrente - nova série IV. Lisboa: Bertrand, 1994. Espaço do Invisivel 5. Lisboa: Bertrand, 1998. 
GÓMEZ AGUILERA, Fernando. "A Estátua e a Pedra: o autor diante do reflexo da sua obra”. In SARAMAGO, José. A estátua e a pedra. Lisboa: Fundação José Saramago, 2013, p.45-59.

LOURENÇO, Eduardo. "Saramago: um teólogo no fio da navalha". O Canto do Signo. Existência e Literatura. Lisboa: Presença, 1993, p.184-188.

MACEDO, Helder. "José Saramago e os caminhos do amor"; "Oito séculos de literatura”. Camóes e outros contemporâneos. Lisboa: Presença, 2017, pp. 185-194; 263-299.

MARTINS, Manuel Frias. A Espiritualidade Clandestina de José Saramago. Lisboa: Fundação José Saramago, 2014.

NIETZSCHE, F. Assim falava Zaratustra (tradução de Paulo Osório de Castro e prefácio de António Marques). Lisboa: Círculo de Leitores, 1996 [1891].

SARAMAGO, José. Memorial do Convento. Lisboa: Caminho, 1982. Cadernos de Lanzarote I. Lisboa: Caminho, 1993.

Cadernos de Lanzarote II. Lisboa: Caminho, 1995. Todos os Nomes. Lisboa: Caminho, 1997. O Homem Duplicado. Lisboa: Caminho, 2002. As Intermitências da Morte. Lisboa: Caminho, 2005. A estátua e a pedra. Lisboa: Fundação José Saramago, 2013.

STEGAGNO PICCHIO, Luciana. "S/título". In SARAMAGO, José. A estátua e a pedra. Lisboa: Fundação José Saramago, 2013, p. 13-16. 